\title{
ACCOUNTING PRACTICES IN ITALIAN HIGHER EDUCATION SYSTEM
}

\author{
Carlotta del Sordo* Rebecca L. Orelli ${ }^{\dagger}$ \\ Emanuele Padovani ${ }^{\ddagger}$
}

Keywords: Higher education system, Reporting, Italy, Accounting systems, Public sector reforms

JEL: M41

\begin{abstract}
The aim of this paper is to investigate whether the accounting systems and techniques in use in higher education system in Italy allow key users to have useful information for a rational decision-making process. The paper develops on a specific case, the Italian context of state and nonstate universities. The research is conducted through a survey addressed to all Italian universities and investigates accounting conditions during the academic year 2008-2009. It reveals the most common approach to the building of the accounting information system and the level of diffusion and development of cost accounting techniques, identifying areas of improvement.
\end{abstract}

*University of Bologna, Department of Management, Piazzale della Vittoria 15, 47121 Forlì, Italy. E-mail: carlotta.delsordo@unibo.it.

${ }^{\dagger}$ University of Bologna, Department of Management, Piazzale della Vittoria 15, 47121 Forlì, Italy. E-mail: PersonNamerebecca.orelli@unibo.it.

¥University of Bologna, Department of Management, Piazzale della Vittoria 15, 47121 Forlì, Italy. E-mail: emanuele.padovani@unibo.it. 


\section{INTRODUCTION}

The Higher Education System (HES) is a community of people carrying out their institutional goals: education through teaching activities and discovery/ innovation through research activities. These are the academic priorities that every university is committed to pursuing. The main purposes of the higher education sector are to advance knowledge and understanding through scholarship and research and to contribute to an economically successful and culturally diverse nation. Universities are supposed to play a central role in the economic and social development process so they have to be accountable to their stakeholders and to clearly communicate how they have managed the public resources.

In Italy, the government has been slow to initiate reforms, but has more recently (since 1989) introduced significant changes in higher education sector determining resources flowing from central government, which contributed to the budgetary devolution, for increasing their autonomy in deciding teaching programmes and accounting and reporting systems. The increased autonomy and the decentralisation of several decisions have indeed given new opportunities to universities, but at the same time it has posed challenges to their management and academic boards, highlighting many difficulties in defining and developing their strategies.

The paper focuses on the role of the accounting and reporting systems in the public sector tertiary education institutions in the Italian context; particularly we put our attention on how accounting information is interpreted and used by key decisions makers in these organizations. The aim of this work is to ascertain whether the accounting information system of state universities is able to support decisions, in a context of rapid and constant transformation. In this vein the research question is the following: Does the accounting system and cost accounting techniques of universities allow users to have all the information for a rational decision process?

This aim is pursued through the development of five sections. The theoretical framework is outlined trough the review of the NPM literature; the idea of university has undergone significant changes in recent years (par. 2). Looking 
over the Italian normative and environmental perspective, particular attention will be paid to those laws and pressures that had a considerable impact on the information needs of such institutions, due to their implication for autonomy, evaluation and planning of the activities (parr. 3.1, 3.2). The mixed effect of both administrative reform and external forces has lead to a new accounting system (par. 3.3). Having clarified the peculiarities of this context, it will be investigated the Italian accounting systems and cost accounting techniques in use in HES. In particular, the paper provides the results of a survey conducted on university, aimed at assessing the actual implementation of the reform (parr. $4,5)^{1}$.

\section{LITERATURE REVIEW}

Since 1990 HEShas been going through a deep revision, together with other areas of public administration. Thus, over the last two decades, public sector reforms have been adopted in many countries. The public sector reforms have given accounting a central role (Hood, 2000, 2005) and many of these reforms show a number of characteristics often summarized in terms of New Public Management (NPM) (Hood, 1991, Osborne and Gaebler, 1992). An accounting dimension is regularly included in public sector reforms (Pollit and Bouckaert, 2004), and that is the reason for the significant volume of research that has been conducted in the field of public sector accounting, widely discussed and described for many countries (OECD, 1997; Pallot, 1999; Pollitt, 2002; Jackson and Lapsley, 2003; Van Helden and Jansen, 2003; Carlin, 2005; Chia and Koh, 2007; Christiaens and Van Peteghem, 2007).

The modernization of the academic system is mainly oriented to make the financial statement more comprehensive and accountable. Further, the academy accounting reform is also linked to the resource allocation system (Spathis and Ananiadis, 2004; Coy and Pratt, 1998), which is related to the performance

\footnotetext{
${ }^{1}$ Paragraphs 1, 2 and 3.1 are to be attributed to Emanuele Padovani, paragraphs 3.2, 3.3 and 4 are to be attributed to Rebecca L. Orelli and paragraphs 5 and 6 are to be attributed to Carlotta del Sordo.
} 
measurement and monitoring process.

In each of the countries where NPM was introduced, a different policy was followed to obtain an efficient and effective organization using private sectorstyle management instruments (Olson et al., 2001).

As a consequence, universities are not only considered as social institutions, but also as "firms" to which certain logic and rules apply, typical of the managerial culture in the private sector, such as the well-known principles of efficiency, effectiveness and accountability. Most financial guidance to universities (Mitchell, 1996) emphasizes the need for private sector accounting techniques and rational costing of courses, departments and other programmes, supporting the use of techniques, such as responsibility accounting, ABC (activity based costing), etc. The underlying logic is that without these NPM-like accounting techniques, it is not possible to appropriately support decisions (Olson et al, 2005).

Accounting reforms were often a first phase of reforming governments, followed by the reform of governmental management, organization, and other parts of public administration. On the other hand, it is possible that accounting reforms have taken place without having a strict NPM perspective in mind (Luder and Jones, 2003), but the accounting reform is an important condition for the success of NPM reforms, because it can be seen as a key ingredient in managerial decision-making process (Pettersen, 2001).

A considerable number of studies have explored accounting changes in the public sector reform (Boston et al., 1996; Hood, 1998). In many of these changes, management techniques were introduced to many public sector organizations. In particular, public universities are facing increasing pressure to be accountable and report performance (Arnaboldi and Azzone, 2004; Christiaens and Wielemaker, 2003; Doost, 1998; Pursglove and Simpson, 2007; Venieris and Cohen, 2004; Welsh and Dey, 2002) to fund agencies, students and the general public. To date, there has been very little research on the type, scope or impact of these performance measurement and reporting activities. Given the importance of the topic (Cullen et al., 2003; Lapsley and Miller, 2004; Parker and Guthrie, 2005; Pounder, 1999), there appears to be an urgent need to begin examining such performance and social reporting (Farneti and Guthrie, 2008; Herremans 
and Allwright, 2000; Gray, 1995).

In many European countries the reforming process affected higher education, with different path and time, however, sharing some common characteristics (OECD, 2003; OECD, 2006) more emphasis on universities' autonomy, both in academic and management issues; the use of financial models for allocating public funds as incentives schemes for promoting better performances; and the role of the assessment procedures and agencies for guaranteeing the quality of educational processes (Deem, 2004; Doost, 1997; Fischer et al., 2004; Goddard and Ooi, 1998; Cropper and Cook, 2000).

\section{ITALIAN HIGHER EDUCATION SYSTEM (HES)}

\subsection{The background of Italian HES}

In Italy HES is provided by many different types of institutions and the overall system is structured in a binary system, consisting of two main articulations: the university and the non-university sector (the latter includes a few specific fields, e.g. archiving, diplomatics, restoration, military studies, etc).

In the 2009-10 academic year the university sector was made up of 89 universities which were classified in state (no. 61) and non-state universities (no. 28, whose 11 are telematic). University is structured as a matrix and staff experiences are shaped on one hand by the Faculties and on the other hand by the Departments. Faculties are responsible for the teaching activity, but departments are the real core of the research activities. State universities (SU) are public entities endowed with scientific, teaching, managerial, financial and book-keeping autonomy. The main governing authorities within a university are the Rector, the Academic Senate and the Board of Directors. For the achievement of common research and teaching purposes, they are endowed with specific structures, such as faculties (schools), departments, institutes, libraries, and service centres. 
Non-State universities (n-SU) have to be legally recognized by a decree of the Ministry of Education. The degree has the same legal value as that of SU. N-SU have to comply with the same general rules and criteria as defined by the national university legislation for SU. The differences between SU and n$\mathrm{SU}$ concern funding and governance. Since n-SU receive less money from the national government, they have a much higher degree of autonomy in fixing entrance fee without any limitations, unlike the State ones. The State recognizes the public value of the n-SU and supplies funds, covering about $10 \%$ of the needs of such universities (for SU about 90\%). This scarcity of fund forced the n-SU to be highly independent from the Ministry that granted them a higher level of autonomy. In country-regionplaceItaly there is not a polarization in terms of public and private universities, since the education is considered by Italian Constitution (article no. 33) a public good and a public responsibility, consequently private universities do not exist. University is and must remain an organization aimed at having and developing the public function of serving the community.

\subsection{The institutional and political issues}

Recent years have witnessed a substantial change in environmental forces that require Universities to become more accountable and financially sustainable, whilst Italian universities pursue their institutional purposes in a very complex situation. The rise in organizational complexity drives universities to manage a large number of students, as well as staff members and activities, because of the widening of access to a greater range of socio-economic groups. This implies a larger amount of students and a growing demand for high quality training. Consequently universities have been introduced to a quasi-market system, where competition among different universities plays an increasing role and constraints the higher education sector to become a global market. At the same time, whilst new international commitments concerning the European unification agenda (such as Bologna Process 1999) strengthen the economic globalization process, Italian decentralization/federalism public policy has sought for by the Education Ministry. 
In this context the decrease of available financial resources caused by the rise of public debt and the expanding of diseconomies, should give an impetus to obtain information on resource consumption. For the first time in metricconverterProductID1993 a1993 a new funding formula has been introduced (from line item budgeting to lump sum budgeting), recognizing an economic responsibility related to the ability to achieve results coherent with defined goals. In fact Law no. $537 / 1993$ made a number of provisions relating to financial autonomy, providing a system of institutional accountability by reforming the funding system.

Considering the level of public and private investment in education, the countryregionItaly's total investment in education is equals $0.7 \%$ of the GNP (Gross national Product), is below the OECD average of $1.4 \%$, whilst the placecountryregionUSA percentage is $2.9 \%$. This puts country-regionItaly, together with country-regionplacePoland, at the last position. The total public expenditure on tertiary education is $1.6 \%$ of total public expenditure in country-regionplaceItaly, well below the OECD countries average (3.1\%). The best performer is countryregionplaceNew Zealand with 5.5\% (OECD, 2010).

The institutional and political factors described are changing the landscape of university education and forcing the path to a season of big legislative renewals within traditional universities in a way that underlines the visibility of accounting and performance management. Accounting literature points out that environmental force are often the main pressure for system changes.

\subsection{The accounting system}

Following many OECD countries the Italian government has been changing academic system rules, giving more autonomy, locally to universities, through a plethora of laws. In 1948 the Constitution declares that «... universities have the right to give themselves an autonomous legal and administrative order, within bounds of what established by state laws» (art. no. 33). Even so only in 1989 Law no. 168 establishes the right to statutory autonomy, promised in the Constitution but never enacted. «Universities are endowed with legal status and, through article 33 of the Constitution, universities have didactical, scientific, organisational, financial and accounting autonomy; the universities 
create their own autonomous systems with statutes and regulations» (art. no. 7). Thus, at present universities do not have to comply with any legislative requirements covering budgets or financial statements set by the State or accounting standards issued by standard setter. Although there are not specific requirements for universities, research shows that institutions mostly have the same financial disclosure as before the introduction of such a great autonomy. Opportunities for radical reforms provided by Law 168/1989 have been largely ignored by the academic community.

This lack of uniformity in providing financial disclosure causes a rather scarce comparability, not only among different universities, but also inside the university itself. Nevertheless the international public sector accounting standards board puts among its main principles the Comparative Information (IPSAS 1, point 48). The time horizon of the budgetary system only covers the short term (one year), whilst no information on the medium-long term are available, consolidated financial statements are neither required nor provided. The extreme fragmentation of accounting practices in universities is generating widespread "evaluation uncertainty" and "accounting anarchy" leading to situations which are difficult to compare and, as a consequence, not at all transparent.

The described heterogeneous situation makes it clearly difficult to compare data of different universities and, not a minor issue, to consolidate the State financial statement. Therefore, a complete accounting autonomy for universities does not appear to be viable, also because the academic system is mainly financed by the community, to which it is essential to provide a more transparent picture about the use of the resources. Financial statements are difficult to be read by stakeholders and to be used for decision-making purposes.

In order to improve the degree of comparability both with the entity's financial statements of previous periods and with the financial statements of other entities (e.g. local governments) the legislative body should prescribe the manner in which financial statements have to be presented. Even though countryregionplaceItaly is among advanced economies in terms of tasks performed, certainly it is an anomaly in accounting terms, considering that its basis of accounting is authorization-based, with mixed accrual criteria. This leaves Italian 
universities with a model that has neither the merits of simplicity typical of the cash basis of accounting nor the merits of reliability typical of the full accrual basis of accounting.

At present universities build up their accounting system by choosing among three alternatives. Under the traditional alternative, they do not introduce accruals accounting, and simply derive their balance sheets and operating statements from their budgetary accounting statements at year-end. Under the parallel-systems alternative, universities do introduce accruals accounting, but keep it completely independent of budgetary accounting to safeguard its specific goals and techniques. Under the integrated-system approach, universities set up an integrated accounting system including both budgetary and accruals accounting (IPSAS 1, point 49).

\section{OBJECTIVES, METHODOLOGY AND DATA COLLECTION}

In order to understand whether the changes in legislation have been effectively played into operative terms, and to verify the consequences of such changes, it will be investigated the Italian accounting systems and cost accounting techniques in use in HES as well as the needs to identify a reporting system able to represent the value of material and immaterial resources, providing an information basis for the creation of knowledge.

Given the structural and institutional specificities and the problems arising in the context in which universities operate and the feasibility of use of business-like tools, this study explores the accounting system features and the cost accounting techniques in the Italian higher education institutions. It has three specific objectives: to ascertain the extent to which Italian universities make use of different types of accounting systems and cost accounting techniques; to identify the specific purposes for which the cost accounting techniques are being used by the adopters; to ascertain the degree of dissemination of the information provided to the different users. 
The paper is based on a country case study in Italian HES. The study is a survey investigating the population of Italian state universities in the academic year 2008-09. For the purpose of the paper a questionnaire was sent to administrative directors or equivalent staff members. The considered variables are namely the type of accounting adopted, the cost accounting techniques used and their purposes and the users of such information provided. The project used a field study methodology to analyze such phenomenon, thus the results of this study cannot be generalized beyond country-regionplaceItaly. However, the results and their implications are of wider interest. The field study approach entails the use of multiple methods of data collections to capture key dimensions of this research. For this reason contemporary to the survey we collected the hard copy of statutes and accounting regulations of the respondent universities.

In 2008-09 country-regionplaceItaly counted 83 universities, and 59 of them are state (including polytechnic institutes, and excluding advanced schools of academic studies and other institutions). We take into account the 59 state universities due to the larger homogeneity of the group, since public universities are subject to the same set of rules, with no exceptions, and the same type of financing, as opposed to what happens in non state universities or in advanced schools of academic studies and other peculiar institutions. The survey, based on a postal questionnaire, was conducted late in 2009 and early 2010. Respondents were requested to answer regarding the academic year 2008-09.

To investigate the Italian accounting systems and cost accounting techniques in Universities the survey is divided into three different sections. The first part aims to determine which of the three kinds of accounting systems is adopted (traditional, integrated and parallel alternative), and sheds light on the quality of information produced for decision processes. Subsequently, some questions on the extent to which cost accounting techniques are in use and the purposes of such use are arisen; this section helps in understanding the kind of techniques implemented and ones that are considered most important for the decision process. The third part concerns the identity of the users of the cost information derived by the information system; this helps to understand the actors that play a role in defining the need of cost accounting information for the decision process and 
the way of satisfying such need.

The questionnaire is mainly comprised of a Likert scale multiple-choice questions. The use of a multiple-choice format has reduced the time used for the analysis of the answers and has undoubtedly facilitated the answers from AD. Nonetheless, this format may have drawn some of the respondents to forego a more complete answer in favour of the provided ones. There were also some open-ended questions, which leave freedom of response. The main advantage of this kind of question is to allow the respondent to answer the question in an unbiased fashion. Ultimately, we chose to use a shared language system and a terminology commonly adopted among the administrative directors. In order to achieve maximum clarity, some questions have been introduced by a short glossary, providing a clarification of the terminology used. Phone solicitation, often followed by mailing of the questionnaire. After said solicitation, the response rate went up to $45.76 \%$ (27 out of 59 ). The dimensional distribution of universities respondent and not respondent to the survey is represented in figure 1 .

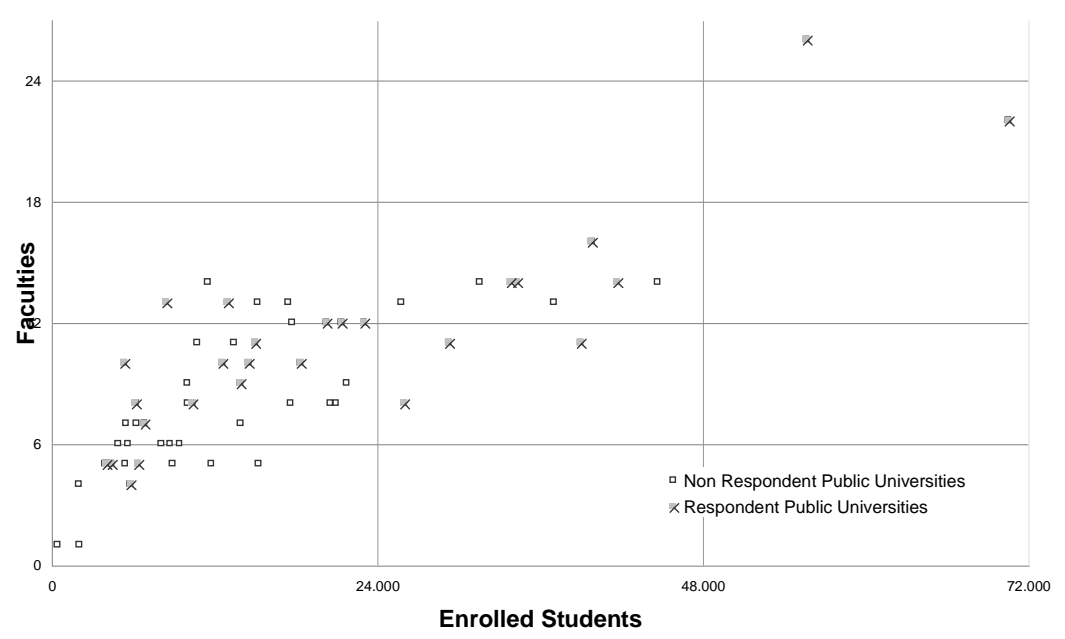

FIGURE 1 - Dimensional Distribution of the Italian Public Universities Source: Authors calculation 
As can be seen in Figure 1the most part of Italian Universities have a number of enrolled students of less than 24.000 people and a number of Faculties comprised between 2 and 14. Then there are 11 Universities with a number of enrolled students between 24.000 and 48.000 people and a higher number of Faculties, between 8 and 16. Lastly there are two so called 'Mega' universities, with more than 48.000 students and more than 22 Faculties.

\section{RESULTS}

Results are presented in relation to the main research question. Do the accounting system and cost accounting techniques of universities allow users to have all the information for a rational decision process? The main research question has been analyzed with reference to the three sub-objective previously defined, namely the kind accounting systems is adopted, to shed light on the information produced; the extent to which cost accounting techniques are in use and the purposes of such use, to understand the kind of techniques implemented and which one are considered most important by users; the users' identity of the cost information, to understand which actors play a role in defining the need of cost accounting information and the way of satisfying such need for the decision process.

Figure 2 provides a summary of the adoption of the accounting system adopted by universities, according with definition of Italian accounting system previously described (traditional, parallel and integrated systems). As can be seen, whilst the $48.15 \%$ of the respondents use the traditional alternative, the integrated system is chosen by the $14.81 \%$ and the $37.04 \%$ of the respondent universities declare to adopt the parallel one. Evidences denote a rather high preponderance of the traditional system (cash basis). This is not surprising considering that universities' autonomy determines the absence of a general mandatory accrualbased accounting. 


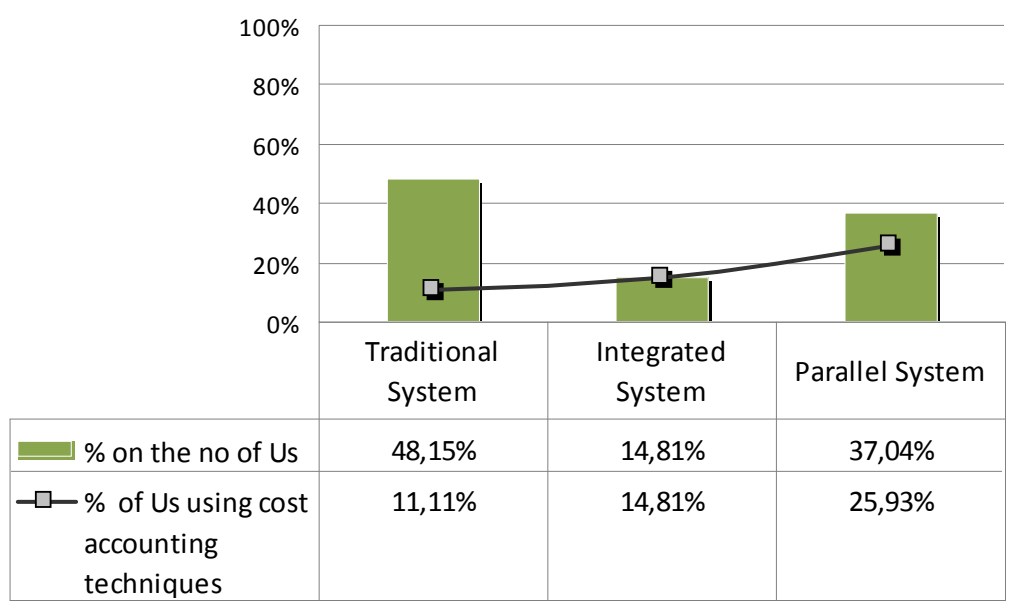

FIGURE 2 - The accounting system

\section{Source: Authors calculation}

The same figure also analyses the number of universities using cost accounting techniques for each accounting alternative. All the institutions that adopt the integrated alternative make use of such kind of techniques, whilst in the case of the parallel system the percentage decreases to $70 \%$ ( $25.93 \%$ on $37.04 \%$ ), still remaining a high value. Finally considering the traditional system the percentage diminishes significantly to $23.08 \%$ ( $11.11 \%$ on $48.15 \%$ ). The major hindrances to the introduction of cost accounting techniques in the university refer to the fact universities are multi-business (didactics and research) and multi-product (courses and research projects) organizations. This causes that they sustain high overhead costs related to central administration, interdepartmental units, libraries, laboratories, etc. Moreover, the strong interrelations among faculties and departments, and their consequent "accounting ambiguity", determine a confusing use of production factors for educational and research processes. Furthermore, universities are a multi-business organization with basically two different institutional purposes, namely education and research, and in which the boundaries of business areas (Faculty and Departments) are highly "blurred" 
and indistinct, sometimes even seamless. Such interconnection provides the Universities their peculiar nature of "Knowledge intensive, public utility service businesses". The result of a research (as a publication), for example, can become an input for the educational process and, on the contrary, the study and the preparation of a course can originate scientific curiosity and bring forth a closer examination of the related topics. After examining the extent to which accounting systems and cost accounting techniques are adopted, we consider the purposes of the implemented accounting techniques. The main purposes of the use of cost accounting techniques for Universities can be identified with the followings: resources consumption analysis, cost reduction, determining cost object, budgeting, make or buy decision. As shown in figure 3, the most successful purpose concerns resources consumption analysis (100\%) and the second and third largest grouping occur with cost reduction (93\%) and determining cost object $(86 \%)$. The remaining purpose of budgeting $(64 \%)$ and make or buy decision $(57 \%)$ have a lower showing across Italian universities. Considering the purposes, results show that Italian universities are heavily engaged with cost accounting techniques whether they are interested in pursuing the first two purposes.

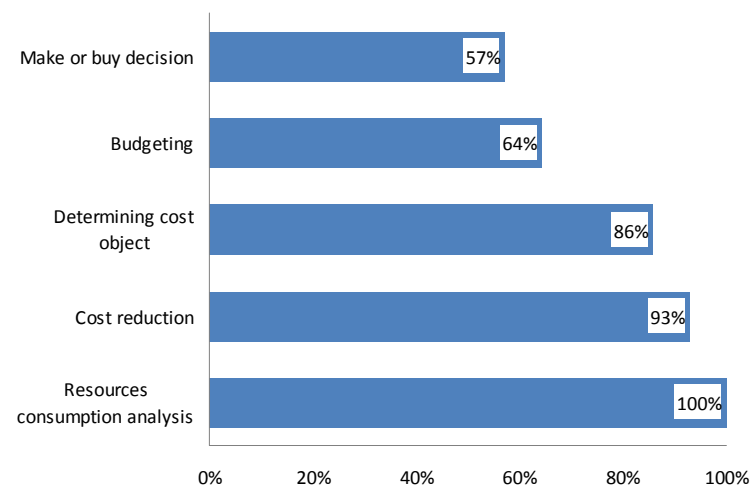

FIGURE 3 - Main purposes of cost accounting techniques implementation Source: Authors calculation 
Having examined the purposes of cost accounting techniques implementation, we now consider the users of the information provided by such adoptions. Results show that all the universities declare that they make use if such information internally, whilst only $14 \%$ makes information available for external users. Of course each university has to comply with compulsory rules giving the required information to external entities, such as the Ministry of Education (Miur), the Audit Commission and the Statistic Institute (Istat) for periodical analysis. Considering the internal users, the most part of them consists of administrative roles (44\%), such as administrative director, executives, and elective roles (35\%), such as chancellor, vice- chancellor, members of the academic senate and of the board. Other internal staff is unit managers, evaluation groups, teachers, etc.

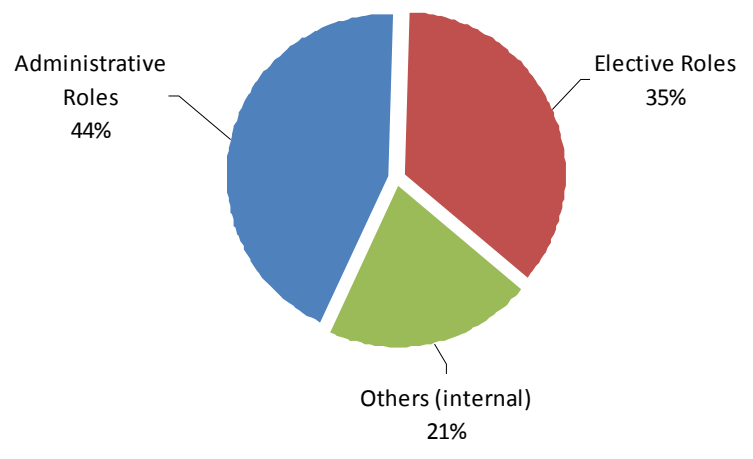

FIGURE 4 - The internal users of information in the universities

Source: Authors calculation 


\section{CONCLUDING REMARKS AND FURTHER DEVELOPMENT}

Universities have always been considered as places where knowledge is created and transferred, playing a fundamental role for the social and economic growth of a country. A strategic priority for any country to ensure an adequate level of wealth and quality of life for its citizens is to develop a high-quality research and didactics. Hence, the need for universities to introduce and apply business criteria and principles in order to adequately combine a good and unbiased administrative action with effective intervention policies by the public administration, efficient resource use and cost-performance in management.

The aim of this work was to ascertain whether the accounting system and cost accounting techniques of universities allow users to have all the information for a rational decision process. The paper focuses on a specific case: the Italian HES investigated thorough a survey. To answer the main research question we investigated three different aspects.

The first aspect is the kind of accounting systems adopted (traditional, integrated and parallel alternative) The survey reveals that the most common kind of accounting system in use is cash based accounting and sheds light on the quality of information produced for decision processes, that are very limited and that is able to inform on the economic aspects of the university only at year end, consequently too late for taking decisions during the year.

The second aspects are about the extent to which cost accounting techniques are in use and the purposes of such use. The survey results show that there is a rather scarce diffusion and a quite limited development of cost accounting techniques. This evidence does not surprise in a system with a large use of a cash basis of accounting, and it helps in understanding why the main purposes of cost accounting techniques are related to resources consumption analysis and cost reduction, kind of information impossible to obtain under a cash accounting system.

Lastly, the third aspect concerns the identity of the users of the cost information derived by the information system, and is seems quite clear that administrative 
roles are the most important actors that play a role in defining the need of cost accounting information for the decision process and the way of satisfying such need.

Gather together these three aspects answer to our main research question, showing that at present the cost accounting system and cost accounting techniques of universities does not allow users to have all the information for a rational decision process.

Particularly, the tools for accounting measurement, which still depend on short term accounting conventions, seems to be inadequate, as they are not able to catch the tangible items and the signals of strategic effectiveness. Moreover, budget, accrual accounting and and-financial reporting systems constitute a necessary managing apparatus, but they are not enough.

The dynamic nature of the competitive environment compels the implementation of multidimensional control tools, such as the balanced scorecard. But "management autonomy" is not to be confused with "accounting autonomy": it is possible to combine a standardization of accounting information for users with a maximum flexibility for accounting and management as in businesses, where accounting rules affect management operation modes only in an extremely mediated way.

The possible implementation of different kind of accounting systems (parallel and integrated alternatives) seems to be in line with the current delegation process of economic responsibilities. In fact, because of the introduction of marketing principles in the academic environment, which has for long banished the concept of competition, the acquisition of competitive advantages will be more and more influenced availability of information provided by the accounting system and better cost accounting techniques.

\section{REFERENCES}

Anessi Pessina, E. and Steccolini, I. (2007), Effects of Budgetary and Accruals accounting coexistence: Evidence from Italian Local Governments, Financial Accountability and Management, 23 (2):113-31. 
Arnaboldi, M. and Azzone, G. (2004), Benchmarking University activities: an Italian case study, Financial Accountability \& Management, 20(2):205-20.

Boston, J., Martin, J., Pallot, J., and Walsh, P. (1996), Public Management: The New Zealand Model, (Auckland: Oxford University Press).

Carlin, T.M. (2005), Debating the Impact of Accrual Accounting and Reporting in the Public Sector, Financial Accountability \& Management, 21(3):309-36.

Chia, Y.M. and Koh, Y.M. (2007), Organizational Culture and the Adoption of Management Accounting Practices in the Public Sector: A Singapore Study, Financial Accountability \& Management, 23(2):189-213.

Christiaens, J. and Van Peteghem, V. (2007), Governmental Accounting Reform: Evolution of the Implementation in Flemish Municipalities, Financial Accountability \& Management, 23(4):375-99.

Christiaens, J., Wielemaker, E. (2003), Financial Accounting Reform in Flemish Universities: An Empirical Study of the Implementation, Financial Accountability \& Management, 19(2):185-204.

Coy D., and Pratt, M. (1998), An insight into accountability and politics in universities: a case study, Accounting, Auditing and Accountability Journal, 11(5):540-61.

Cropper, P. and Cook, R. (2000), Activity-Based Costing in Universities Five years on, Public Money \& Management, 20(2):61-8.

Cullen, J., Joyce, J., Hassal, T. and Broadbent, M. (2003), Quality in higher education: from monitoring to management, Quality Assurance in Education, 11(1):5-14.

Deem, R. (2004), The knowledge worker, the manager-academic and the contemporary UK university: new and old forms of public management?, Financial Accountability \& Management, 20(2):107-28.

Doost, R. K. (1998), Financial accountability: a missing link in university financial reporting systems, Managerial Auditing Journal, 13(8):479-88.

Doost, R. K. (1997), What is the cost of running a university? An unresolved dilemma!, Managerial Auditing Journal, 12(2):91-3.

Farneti, F. and Guthrie, J. (2008), GRI Sustainability Reporting by Australian Public Sector Organizations, Public Money \& Management, 28(6):345- 
52.

Fischer, M., Gordon, T. P., Greenlee, J. and Keating, E. K. (2004), Measuring operations: an analysis of us private colleges and universities' financial statements, Financial Accountability \& Management, 20(2):129-51.

Goddard, A. and Ooi, K. (1998), Activity-Based Costing and Central Overhead Cost Allocation in Universities: A Case Study, Public Money \& Management, Vol. July-September, 31-8.

Gray, R., Kouhy, R. and Lavers, S. (1995), Corporate social and environmental reporting. A review of the literature and a longitudinal study of UK disclosure, Accounting Auditing and Accountability Journal, 8(2):47-77.

Guthrie, J., Humphrey, C., Jones, L., \& Olson, O. (Eds.). (2005). International public financial management reform: Progress, contradictions and challenges. Greenwich, Conneticut: Information Age Publishing.

Herremans, I. and Allwright, D.E. (2000), Environmental management systems at North American universities. What drives good performance?, International Journal of Sustainability in Higher Education, 1(2):168-81.

Hood, C. (1991), A Public Management for All Seasons, Public Administration, 6(3):3-19.

Hood, C. (2000), Paradoxes of Public-Sector Managerialism, Old Public Management and Public Service Bargains, International Public Management Journal, 3:1-20.

Hood, C. (2005), Public Management: The Word, the Movement, the Science in Ferlie E., Lynn L.E. and Pollitt C. (eds.), The Oxford Handbook of Public Management, Oxford, OUP.

Hood, C., Baldwin, R. and Scott, C. (1998, eds), A Reader on Regulation, Oxford, OUP.

IPSAS 1 (2006) - Presentation of financial statements, december, IFAC

Jackson, A. and Lapsley, I. (2003), The diffusion of accounting practices in the new managerial public sector, The International Journal of Public Sector Management, 16(5):359-72.

Lapsley, I. and Miller, P. (2004), Transforming Universities: The Uncertain, Erratic Path, Financial Accountability \& Management, 20(2):103-06. 
Luder, K. and Jones, R. (2003, eds.), Reforming Governmental Accounting and Budgeting in Europe (Frankfurt Fachverlag Moderne Wirtschaft).

Mitchell, M. (1996), Activity-Based Costing in UK Universities, Public Money \& Management, 16(1):55-7.

OECD (2010), Education at a glance. 2010 edition, Paris, OECD.

OECD (2003), Education Policy Analysis, Paris, OECD.

OECD (1997), In Search for Results: Performance Management Practices, Paris: PUMA/OECD.

Olson, O., Humphrey, C. and Guthrie, J. (2001), Caught in an Evaluatory Trap: A Dilemma for Public Services Under NPFM, The European Accounting Review, 10(3):505-22.

Osborne, D. and Gaebler, T. (1992), Reinventing Government, Harmondsworth: Penguin Books.

Pallot, J. (1999), Beyond NPM: Developing Strategic Capacity, Financial Accountability \& Management, 15(3-4):419-26.

Parker, L. and Guthrie, J. (2005), Welcome to "the rough and tumble": Managing accounting research in a corporatised university world, Accounting, Auditing \& Accountability Journal, 18(1):5-13.

Pettersen, I.J. (2001), Implementing Management Accounting Reforms in the Public Sector: The Difficult Journey from Intentions to Effects, The European Accounting Review, 10(3):561-81.

Pollitt, C. and Bouckaert, G. (2004), Public Management Reform. A Comparative Analysis, Oxford University Press, London.

Pollitt, C. (2002), The New Public Management in International Perspective; an Analysis of Impacts and Effects, in Mc Laughlin K., Osborne S.T. and Ferlie E. (eds.), New public management, The current trends and future prospects (Routledge), pp. 274-292.

Pounder, J. (1999), Institutional performance in higher education: is quality a relevant concept?, Quality Assurance in Education, 7(3):156-63.

Pursglove, J. and Simpson, M. (2007), Benchmarking the performance of English universities, Benchmarking: An International Journal, 14(1):102-22.

Spathis, C. and Ananiadis, J. (2004), The accounting system and resource 
allocation reform in a public university, The International Journal of Educational Management, 18(3):196-204.

Van Helden, G.J. and Jansen, E.P. (2003), New Public Management in Dutch Local Government, Local Government Studies, 29(2):68-88.

Venieris, G. and Cohen, S. (2004), Accounting Reform in Greek Universities: A Slow Moving Process, Financial Accountability \& Management, 20(2):183204.

Welsh, J. and Dey, S. (2002), Quality measurement and quality assurance in higher education, Quality assurance in Education, 10(2):17-25.

\section{RAČUNOVODSTVENE PRAKSE U TALIJANSKOM SUSTAVU VISOKOG ŠKOLSTVA}

Sažetak

Cilj ovog rada je istražiti da li računovodstveni sistemi $i$ tehnike korišteni u talijanskom sustavu visokog školstva korisnicima daju korisne informacije za racionalni proces donošenja odluka. Rad se razvija na specifičnom slučaju, talijanskom kontekstu državnih i nedržavnih sveučilišta. Istraživanje je provedeno putem ankete poslane svim talijanskim sveučilištima i istražuje računovodstvene uvjete u akademskoj godini 2008-2009. Otkriva najuobičajeniji pristup izgradnji računovodstvenog informatičkog sistema $i$ razinu rasprostranjenosti $i$ razvoja tehnika troškovnog računovodstva, ukazujući na mjesta za poboljšanje.

Ključne riječi: sustav visokog školstva, izvješćivanje, Italija, sveučilišta, računovodstveni sustavi, tehnike troškovnog računovodstva, reforme javnog sektora, prakse 